\title{
Effects of straw mulching on microclimate characteristics and evapotranspiration of drip-irrigated winter wheat in North China Plain
}

\author{
Jiandong Wang ${ }^{1}$, Yanqun Zhang ${ }^{1}$, Shihong Gong ${ }^{1}$, Di Xu ${ }^{1 *}$, Richard Snyder ${ }^{2}$, \\ Yanyu Chen ${ }^{3}$, Yuefen Zhao ${ }^{3}$, Qinghong Yan $^{1}$ \\ (1. State Key Laboratory of Simulation and Regulation of Water Cycle in River Basin, China Institute of Water Resources \\ and Hydropower Research, Beijing 100048, China; 2. University of California, Davis, CA 95616, USA; \\ 3. Beijing IWHR Corporation, China Institute of Water Resources and Hydropower Research, Beijing 100048, China)
}

\begin{abstract}
Field experiments were conducted for two consecutive years (2013-2014 and 2014-2015) to study the effects of straw mulching on microclimate characteristics, energy flux, soil evaporation $\left(E_{s}\right)$ and evapotranspiration of winter wheat (Triticum aestivum L.) under adequate drip irrigation in North China Plain (NCP). The results revealed that straw mulching affected air temperature $\left(T_{a}\right)$ and dew point temperature $\left(T_{d}\right)$ near the soil surface but had little effect on relative humidity $(R H)$ compared with non-mulched fields. Straw mulching increased the turbulent exchange coefficient $(K)$, and $K$ within the canopy was higher than that above the canopy. Straw mulching clearly increased the sensible heat flux $(H)$ distribution in April-June, and part of the energy needed for evapotranspiration was provided by transfer from the warmer air aloft. There was a linear functional relationship between $H$ and $T_{a}$ measured above and within the canopy. The straw mulching decreased $E_{s}$ but increased crop transpiration $(T)$. Mulched treatment $(T M)$ can decrease the total irrigation amount by about $7 \%-15 \%$ compared with the non-mulched treatment $(T N)$. There were no significant differences $(p>0.05)$ in cumulative crop evapotranspiration $\left(E T_{c}\right)$ between $T M$ and $T N$ treatments under adequate drip irrigation, and the use of mulch may need to be combined with an optimal deficit drip irrigation schedule for managing the declining water table in NCP.
\end{abstract}

Keywords: drip irrigation, microclimate, straw mulching, winter wheat, evapotranspiration, water use efficiency DOI: $10.25165 /$ j.ijabe.20181102.3192

Citation: Wang J D, Zhang Y Q, Gong S H, Xu D, Snyder R, Chen Y Y, et al. Effects of straw mulching on microclimate characteristics and evapotranspiration of drip-irrigated winter wheat in North China Plain. Int J Agric \& Biol Eng, 2018; 11(2): $122-131$.

\section{Introduction}

Winter wheat (Triticum aestivum L.) is a major crop and accounts for approximately $71 \%$ of all wheat production in China ${ }^{[1]}$. In North China Plain (NCP). The annual rainfall is extremely variable with more than $70 \%$ concentrated in the maize-growing season (July-September). Precipitation in the winter wheat-growing season (October-June) is only about $60-150 \mathrm{~mm}^{[2]}$, and crop evapotranspiration $\left(E T_{c}\right)$ is approximately $450 \mathrm{~mm}^{[3]}$. As a consequence, irrigation (mainly from groundwater) is essential to maintain high winter wheat yield. Winter wheat

\section{Received date: 2017-01-10 Accepted date: 2017-10-03}

Biographies: Jiandong Wang, PhD, Professor, research interests: agricultural water and soil engineering, efficient irrigation technology and products, Email: wangjd@iwhr.com; Yanqun Zhang, PhD, Associate Professor, research interests: agricultural water and soil engineering, efficient water management in agriculture, Email: zhangyq@iwhr.com; Shihong Gong, PhD, Professor, research interests: agricultural water and soil engineering, efficient irrigation technology and products, Email: gshh@iwhr.com; Richard Snyder, PhD, Professor, research interests: plant physiology, Email: rlsnyder@ucdavis.edu; Yanyu Chen, Bachelor, Senior Engineer, research interests: hydraulic engineering, Email: imexb@126.com; Yuefen Zhao, Master, Senior Engineer, research interests: agricultural water and soil engineering, Email: zhao801030@163.com; Qinghong Yan, PhD, Associate Professor, research interests: agricultural water and soil engineering Email: yanqh@iwhr.com;

*Corresponding author: $\mathrm{Di} \mathbf{X u}, \mathrm{PhD}$, Professor, research interests: agricultural water and soil engineering, efficient irrigation and drainage. China Institute of Water Resources and Hydropower Research, No.20 Chegongzhuang West Road, Haidian District, Beijing 100048, China. Tel: +86-10-68786535, Fax: +86-10-68451169, Email: xudi@iwhr.com. irrigation accounts for about $70 \%$ of irrigation water use in $\mathrm{NCP}^{[4]}$. Thus, to avoid overexploitation of groundwater, and to promote sustainable crop production, a combined approach that uses efficient irrigation methods and optimal water management is needed $^{[5-7]}$.

Adopting irrigation practices to reduce $\mathrm{ET}_{\mathrm{c}}$ while maintaining yield is extremely important in this region. Consequently, sprinkler irrigation has gradually gained local popularity with the increasing shortage of water resources. As the water resources situation worsens in NCP, studies ${ }^{[7-9]}$ on the use of micro-irrigation methods, such as surface drip irrigation, are increasingly being applied to raise water use efficiency (WUE), which is computed as the crop yield divided by the seasonal $\mathrm{ET}_{\mathrm{c}}$.

Throughout the winter wheat-growing season in NCP, soil evaporation $\left(E_{s}\right)$ accounts for more than $30 \%$ of crop $E T_{c}^{[10-12]}$. Since $E_{s}$ does not necessarily enhance crop production, many researchers consider using straw mulching as a strategy to reduce $E_{s}$ and to increase WUE ${ }^{[13-15]}$. For example, Nath and Sarma ${ }^{[16]}$ reported that mulching conserved soil moisture, maintained a more even soil temperature, suppressed weed growth and increased soil organic matter. Chen et al. ${ }^{[17]}$ reported that mulching reduced $E_{s}$ by $21 \%$ when they applied $3000 \mathrm{~kg} / \mathrm{hm}^{2}$ less mulch than the traditional practice in NCP. When they applied $6000 \mathrm{~kg} / \mathrm{hm}^{2}$ more mulch than the traditional practice, evaporation was reduced by $40 \%$. However, because yield was also reduced, the overall WUE was not improved by mulching. Some research results revealed that straw mulching can significantly increase crop yield $^{[18-20]}$, probably because of higher soil moisture ${ }^{[21]}$. However, 
because crop response is affected by complex interactions between mulch mass and factors such as irrigation frequency, evaporative potential and soil texture, mulch has not always increased yield $^{[17,21,22]}$. Li et al. ${ }^{[22]}$ investigated the effects of straw mulching on soil moisture and temperature, showing that straw mulching increased the soil temperature from January to February but decreased the soil temperature after February. Their results also indicated that straw mulching may decrease the yield and WUE of winter wheat in NCP.

There is minimal literature on mutual influence mechanisms relating to straw mulching, microclimate and $E T_{c}$ characteristics. Therefore, it is needed to clarify the mechanisms related to how mulching affects field microclimate characteristics, energy distribution and $E T_{c}$, which may affect crop development and final yield. With the rapidly increasing use of combined harvesters, straw from summer maize crops is commonly used to mulching the succeeding winter wheat crops in NCP. Furthermore, Farmers in NCP will still prefer to use an adequate or even an excessive irrigation schedule for their winter wheat, because they believe that the application of more water may result in a much higher return in yield. Thus it is also important to determine if the use of straw mulch on winter wheat will be a beneficial tool for the management of the declining water table in NCP or in other parts of the world under adequate irrigation.

The objectives of this study were to: (1) investigate the effects of drip irrigation and straw mulching on the microclimate characteristics of winter wheat farmland; (2) research the energy flux change mechanism and its relevance to surrounding microclimate parameters under mulching and non-mulching conditions; and (3) study the effects of drip irrigation and straw mulching on $E_{s}$ and $E T_{c}$ of winter wheat.

\section{Materials and methods}

\subsection{Experimental site}

Field experiments were conducted at the Irrigation Experiment Station at the China Institute of Water Resources and Hydropower Research at Daxing, south of Beijing (39 $37^{\circ} \mathrm{N}$ latitude, $116^{\circ} 25^{\prime} \mathrm{E}$ longitude, elevation $30 \mathrm{~m}$ above sea level). In this region of NCP there is a silt loam soil formed by deposits of the loess formations ${ }^{[7,23]}$. The primary soil hydraulic properties are field capacity (FC) of $0.31 \mathrm{~m}^{3} / \mathrm{m}^{3}$ and bulk density of $1.58 \mathrm{~g} / \mathrm{cm}^{3}$ in the crop root zone ( $1 \mathrm{~m}$ in depth), and permanent wilting point of $0.11 \mathrm{~m}^{3} / \mathrm{m}^{3}$.

An automatic weather station (Monitor Sensors, Caboolture, QLD, Australia) at the experimental station provided measurements of solar radiation, air temperature $\left(T_{a}\right)$, relative humidity $(R H)$ and wind speed at $2 \mathrm{~m}$ height; precipitation measurements were performed above green grass. Data were recorded every $30 \mathrm{~min}$. The climatic characterization is presented in Table 1.

\subsection{Experimental design}

Field experiments with winter wheat (Triticum aestivum L. cv. Zhongmai 9) were conducted for two growing seasons (2013-2014 and 2014-2015). Surface drip irrigation was used for irrigation of all treatments. The two experimental treatments were with straw mulch (TM) and without straw mulch (TN). All the treatments were irrigated to avoid water stress, and each treatment had three replicates. The total experimental area was $62 \mathrm{~m} \times 42 \mathrm{~m}$, equally divided into two parts separated by non-irrigated alleys of $2 \mathrm{~m}$ wide, with one zone for the TM and the other for TN. For TM or TN treatment, each experimental treatment replicate plot measured
Table 1 Average Climatic data summary during 2013-2015 for winter wheat growing seasons at Daxing in NCP

\begin{tabular}{|c|c|c|c|c|c|c|c|c|}
\hline \multirow[t]{2}{*}{ Month } & \multicolumn{2}{|c|}{$\begin{array}{l}\text { Air temperature } \\
{ }_{/{ }^{\circ} \mathrm{C}}\end{array}$} & \multicolumn{2}{|c|}{$\begin{array}{l}\text { Solar net } \\
\text { radiation } \\
/ \mathrm{MJ} \cdot \mathrm{m}^{-2} \cdot \mathrm{d}^{-1}\end{array}$} & \multicolumn{2}{|c|}{$\begin{array}{l}\text { Wind speed } \\
\qquad / \mathrm{m} \cdot \mathrm{s}^{-1}\end{array}$} & \multicolumn{2}{|c|}{$\begin{array}{l}\text { Precipitation } \\
/ \mathrm{mm}\end{array}$} \\
\hline & 2013-14 & $2014-15$ & 2013-14 & 2014-15 & 2013-14 & 2014-15 & 2013-14 & 2014-15 \\
\hline Oct & 12.25 & 12.86 & 3.71 & 3.22 & 0.66 & 0.53 & 9.40 & 12.95 \\
\hline Nov & 4.69 & 5.10 & 0.90 & 1.03 & 1.06 & 0.66 & 0 & 0.76 \\
\hline Dec & -1.81 & -1.96 & -0.61 & -0.30 & 1.01 & 0.93 & 0 & 0.76 \\
\hline Jan & -2.20 & -1.88 & -0.27 & 0.13 & 1.05 & 1.10 & 0 & 1.02 \\
\hline Feb & -1.52 & 0.32 & 1.45 & 1.06 & 1.20 & 1.17 & 5.59 & 8.38 \\
\hline Mar & 8.81 & 7.77 & 4.81 & 3.51 & 1.40 & 1.48 & 7.62 & 3.56 \\
\hline Apr & 15.84 & 14.78 & 8.06 & 7.28 & 0.97 & 1.52 & 27.94 & 32.00 \\
\hline May & 20.94 & 20.73 & 10.28 & 9.83 & 1.08 & 1.12 & 36.83 & 36.07 \\
\hline June & 24.21 & 24.20 & 11.43 & 8.77 & 0.43 & 0.88 & 50.8 & 16.51 \\
\hline
\end{tabular}

$20 \mathrm{~m} \times 20 \mathrm{~m}$, separated by non-irrigated alleys of $0.6-0.7 \mathrm{~m}$ wide. The space between drip lines was $0.5 \mathrm{~m}$, conforming to the row spacing of winter wheat. A flow meter was used to measure the amount of water applied to each treatment and a valve was used to control irrigation.

After harvest of the maize cobs, the remaining stalk material was chopped with a mechanical chopper, resulting in a layer of $5-10 \mathrm{~cm}$ pieces in field. The treatment was prepared by removing the chopped material, then sowing the wheat. After seedling emergence, the straw mulch was spread to a thickness of 2-3 cm (about $6000 \mathrm{~kg} / \mathrm{hm}^{2}$ ).

\subsection{Crop management and irrigation scheduling}

Winter wheat (Triticum aestivum L. cv. Zhongmai 9) was sown on October 11, 2013 and October 13, 2014 at a row spacing of $25 \mathrm{~cm}$. Seedling density was approximately $500-600$ plants $/ \mathrm{m}^{2}$. To promote the germination and establishment, the winter wheat in each plot was irrigated with approximately $67 \mathrm{~mm}$ water prior to the winter freeze (December 10, 2013; December 6, 2014), which is a practice widely employed in NCP. Fertilizer applications were the same for all treatments. For each treatment, $155 \mathrm{~kg}$ $\mathrm{N} / \mathrm{hm}^{2}$ of nitrogen $\left(\mathrm{CO}\left(\mathrm{NH}_{2}\right)_{2}\right)$ was applied by injection into a fertilizer tank connected to the drip irrigation systems at the stem-elongation growth stage of winter wheat.

The growing season of winter wheat was divided into four phases that were considered most relevant from the viewpoint of its response to irrigation ${ }^{[11]}$. In this study, irrigation scheduling was based on soil moisture deficit in the effective root zone at each irrigation event. When the soil moisture in the effective root zone reached designated lower limit (explained below), water was applied up to designated upper limit range. The amount of irrigation water applied by drip irrigation in each irrigation event to replace the soil water depletion was calculated as Equation $(1)^{[24]}$ :

$$
I=H\left(\theta_{u p}-\theta_{0}\right) p_{w} / \eta
$$

where, $I$ is the application amount, $\mathrm{mm} ; H$ is the effective rooting depth, $\mathrm{mm} ; \theta_{u p}$ is the volumetric water content at the upper limit of a treatment during certain growth stages, $\mathrm{m}^{3} / \mathrm{m}^{3} ; \theta_{0}$ is the average volumetric water content in the effective rooting depth at the time of irrigation (i.e., the lower limit); $P_{w}$ is the percentage of wetted surface area, $\mathrm{m}^{3} / \mathrm{m}^{3} ; \eta$ is the application efficiency. In this study, the $p_{w} \approx 60 \%$ and $\eta=90 \%$.

The irrigation lower and upper limits for TM and TN treatments were the same, corresponding to irrigation scheduling at a threshold range of $60 \% \mathrm{FC}\left(0.19 \mathrm{~m}^{3} / \mathrm{m}^{3}\right)$ to $100 \% \mathrm{FC}$ during the winter wheat-growing period. During the recovery and 
stem-elongation phases, the average volumetric water content level was measured within the rooting depth range of 0-60 cm. During the heading and grain-filling stages, a $0-80 \mathrm{~cm}$ effective rooting depth was assumed ${ }^{[24]}$. TM and $\mathrm{TN}$ treatments were both considered well-watered treatments ${ }^{[7,25]}$.

\subsection{Measurement of soil water}

The soil water content was measured 3-5 d prior to each irrigation application during the experiments. For each treatment plot, soil samples were taken at positions directly under the emitters at soil depth ranges of $0-20 \mathrm{~cm}, 20-40 \mathrm{~cm}, 40-60 \mathrm{~cm}$, $60-80 \mathrm{~cm}$ and $80-100 \mathrm{~cm}$; soil water content was determined by the gravimetric method and was converted to a percentage volumetric basis by multiplying the values by the bulk density of the soil of the respective layer.

\subsection{Energy balance measurement}

The surface energy balance of winter wheat field (Equation. (2)) can be written as:

$$
R_{n}=\lambda E+H+G
$$

where, $R_{n}$ is the net radiation, and $\lambda E, H$ and $G$ are the latent heat flux, sensible heat flux and soil heat flux, respectively (all in units of $\mathrm{W} / \mathrm{m}^{2}$ ). In Equation (2), for $R_{n}$ and $G$ toward the surface is positive; for $\lambda E$ and $H$, away from the surface is positive. In this experiment, $R_{n}$ was measured by net radiometer mounted $1.0 \mathrm{~m}$ above the canopy of winter wheat at $30 \mathrm{~min}$ intervals. Soil heat flux $(G)$ was measured using soil heat flux plates installed at $20 \mathrm{~mm}$ depth in the soil; data were averaged over 30 min periods. All the sensors were connected to a data logger (model CR3000, Campbell Scientific Inc., Logan, Utah, USA). The latent heat flux density was calculated using the Penman-Monteith equation (Equation (3)) ${ }^{[26]}$ :

$$
\lambda E=\frac{\Delta\left(R_{n}-G\right)+\rho_{a} C_{p}^{\frac{\left(e_{s}-e_{a}\right)}{r_{a}}}}{\Delta+\gamma\left(1+\frac{r_{s}}{r_{a}}\right)}
$$

where, $\lambda E$ is the latent heat flux density, $\mathrm{W} / \mathrm{m}^{2} ; E$ is the mass flux density of water vapor per half hour, $\mathrm{kg} / \mathrm{m}^{2} \cdot 0.5 \mathrm{~h} ; \lambda$ is the latent heat of vaporization $\left(\approx 2.45 \times 10^{6} \mathrm{~J} / \mathrm{kg}\right) ; R_{n}$ is the net radiation $\left(\mathrm{W} / \mathrm{m}^{2}\right) ; G$ is the soil heat flux, $\mathrm{W} / \mathrm{m}^{2} ;\left(\mathrm{e}_{\mathrm{s}}-\mathrm{e}_{\mathrm{a}}\right)$ represents the vapor pressure deficit of the air, $\mathrm{kPa} ; \rho_{a}$ is the mean air density at constant pressure $\left(\approx 1.29 \mathrm{~kg} / \mathrm{m}^{3}\right) ; c_{p}$ is the specific heat of moist air at constant pressure $(\approx 1013 \mathrm{~J} / \mathrm{kg} \cdot \mathrm{K}) ; \Delta$ represents the slope of the saturation vapor pressure temperature relationship, $\mathrm{kPa} / \mathrm{K} ; \gamma$ is the psychrometric constant $(\approx 0.067 \mathrm{kPa} / \mathrm{K})$; and $r_{s}$ and $r_{a}$ are the (bulk) surface and aerodynamic resistances, $\mathrm{s} / \mathrm{m}$. This combination method has been developed further by many researchers and extended to cropped surfaces by introducing resistance factors. One can use the equation for the direct calculation of any $E T_{c}$ using crop-specific surface and aerodynamic resistances ${ }^{[27]}$. $(4)^{[27,28]}$

The aerodynamic resistance $\left(r_{a}\right)$ was calculated as Equation

$$
r_{a}=\frac{\ln \left[\frac{Z_{m}-d}{Z_{o m}}\right] \ln \left[\frac{Z_{h}-d}{Z_{\text {oh }}}\right]}{k^{2} u_{z}}
$$

where, $r_{a}$ is the aerodynamic resistance, $\mathrm{s} / \mathrm{m} ; Z_{m}$ is the height of wind measurements $(=2 \mathrm{~m}) ; Z_{h}$ is the height of humidity measurements $(=2 \mathrm{~m}) ; d$ is the zero plane displacement height $(\mathrm{m})$, $d=2 / 3$ height of crop $^{[29,30]} ; Z_{o m}$ is the roughness length governing momentum transfer $(\mathrm{m}), Z_{\text {om }}=0.123$ height of $\operatorname{crop}^{[31]} ; Z_{o h}$ is the roughness length governing transfer of heat and vapor $(\mathrm{m}), Z_{\text {oh }}=$ $0.1 Z_{\text {om }}{ }^{[31]} ; k$ is the von Karman's constant $(=0.41)$ and $u_{z}$ is the wind speed at height $z(\mathrm{~m} / \mathrm{s})$. To simplify the calculation, a linear regression equation between $r_{a}$ and wind speed (Figure 1) was determined using $r_{a}$ measured in the field and the reciprocal of wind speed measured at $2 \mathrm{~m}$ height from both 2014 and 2015. As shown in Figure 1, the equation $r_{a}=80.01 U^{-1}{ }_{2}+16.93$, provided a good estimate of $r_{a}$ with $R^{2}=0.90$.

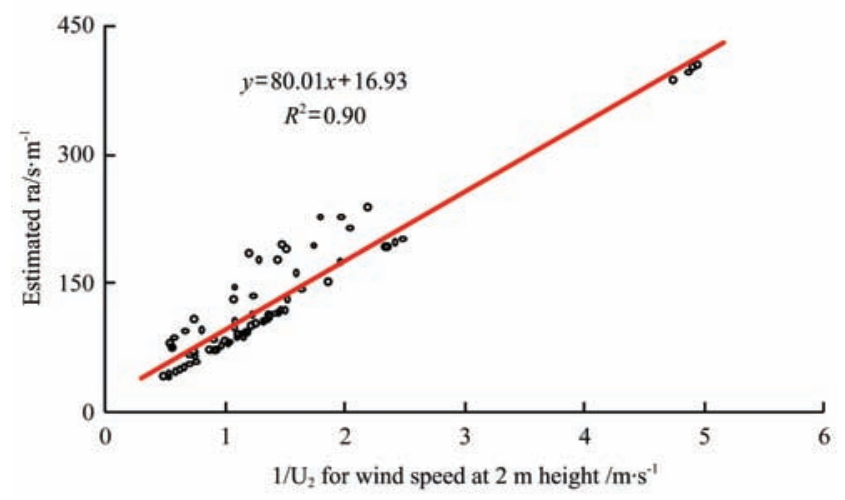

Figure 1 Regression relationship between the aerodynamic resistance $\left(r_{a}\right)$ and the reciprocal of wind speed measured at $2 \mathrm{~m}$ height for winter wheat field from both 2014 and 2015 testing data

The (bulk) surface resistance $\left(r_{s}, \mathrm{~s} / \mathrm{m}\right)$ was calculated from Allen, R. G et al. ${ }^{[27,32]}$ (Equation (5)) as:

$$
r_{s}=\frac{r_{L}}{L A I_{\text {eff }}}
$$

where, $r_{L}$ is the bulk stomatal resistance of the well-illuminated leaf, $\mathrm{s} / \mathrm{m}$; and LAI is an estimate of the leaf area index (LAI) that is effectively contributing to transpiration $(T)$. Several studies have indicated that the value for $\lambda E$ calculated from the Penman-Monteith equation has low sensitivity to the value for $r_{L}$, although $r_{L}$ varies during the course of $1 \mathrm{~d}$ with levels of solar radiation, leaf temperature and vapor pressure gradient ${ }^{[26,33-35]}$. In this study, daylight values for $r_{L}$ were measured using a portable Li-Cor 6400 portable photosynthesis system (Li-cor company, USA) during every growth stage at 8:00, 10:00, 12:00, 14:00, and $16: 00$, and four sunny days were chosen to test every growth stage of winter wheat. The mean value of $r_{L}$ was used to calculate the (bulk) surface resistance $\left(r_{s}\right)$ at every growth stage of winter wheat, and when the net radiation $\left(R_{n}\right)$ value was negative. Following the procedures in Allen et al. ${ }^{[32]}, 200 \mathrm{~s} / \mathrm{m}$ was used as the nighttime $r_{s}$ and as the daytime maximum $r_{s}$.

$L A I_{\text {eff }}$ is the mean effective $L A I$ contributing to $\mathrm{T}$ by the crop, and Ben-Mehrez et al. ${ }^{[36]}$ suggested an expression for $L A I_{\text {eff }}$ of semi-dense agricultural crops based on data from Shuttleworth and Rochette et al. (Equation (6)) ${ }^{[37,38] \text {. }}$

$$
L A I_{\text {eff }}=\frac{L A I}{0.3 L A I+1.2}
$$

where, the $L A I$ for different growth stages was measured following the procedures of Duchemin ${ }^{[39]}$; more details were given in Wang et al. ${ }^{[7]}$.

\subsection{Air temperature, dew point temperature, humidity and soil surface temperature}

$T_{a}$, dew point temperature $\left(T_{d}\right)$ and $R H$ were recorded automatically by automatic U23 Pro v2 Temperature/Relative Humidity sensor (HOBO; Onset Computer Co., Bourne, MA, USA) every $15 \mathrm{~min}$ at several heights over one of the TM and one of the TN plots. The "near-surface" measurement height was $15 \mathrm{~cm}$ above the soil surface, and the $T_{a}$ readings used the symbols TM1 and TN1 for TM and TN treatments, respectively. The $T_{d}$ 
readings used $T M-D_{\mathrm{dn}}$ and $\mathrm{TN}-\mathrm{D}_{\mathrm{dn}}$ for $\mathrm{TM}$ and $\mathrm{TN}$ treatments, respectively. The RH measurements at the same height were called TM-dn and TN-dn for TM and TN treatments, respectively.

The second set of data were collected at an "above-canopy" measurement height, where the sensors were maintained at a height of $30 \mathrm{~cm}$ above the wheat canopy throughout the season (so they were moved upwards as the canopies grew). The $T_{a}$ measurements used TM2 and TN2, the $T_{d}$ readings used TM- $\mathrm{D}_{\text {up }}$ and TN-D up and the RH data used TM-up and TN-up, respectively, as symbols for the variables. Soil temperature data for TM and TN treatments were collected with Optic sensors (HOBO; Onset Computer Co., Bourne, MA, USA).

\subsection{Turbulent exchange coefficient}

The turbulent exchange coefficient $K\left(\mathrm{~m}^{2} / \mathrm{s}\right)$ was calculated using the following equation ${ }^{[40]}$ :

$$
k=\frac{\Delta z\left(R_{n}-G\right)}{\rho_{a} C_{p} \Delta T+\rho_{a} \lambda \Delta q}
$$

where, $\Delta Z=Z_{2}-Z_{1}$ is the difference of two measurement heights. For above-canopy calculations, $Z_{1}$ is the crop height plus $0.3 \mathrm{~m}$ and $Z_{2}$ is measured at $2 \mathrm{~m}$ above the ground. For the below-canopy calculations, $Z_{2}$ is the crop height plus $0.3 \mathrm{~m}$ and $Z_{l}$ is $0.15 \mathrm{~m} . \Delta T$ is the difference of $T_{a}$ corresponding to $Z_{1}$ and $Z_{2}$ heights, and the $\Delta q=q_{1}-q_{2} \approx 6.22 \times 10^{-3}\left(e_{1}-e_{2}\right)$ is the difference in specific humidity $(\mathrm{g} / \mathrm{g})$ at the two heights, where $e_{1}$ and $e_{2}$ are the actual vapor pressures $(\mathrm{kPa})$ corresponding to heights $Z_{1}$ and $Z_{2}$. The vapor pressures are calculated from $\mathrm{RH}$ and $\mathrm{T}_{\mathrm{a}}$ measurements (section 2.6). Other parameters in Equation (7) were already described before section 2.7 .

\subsection{Soil evaporation and crop evapotranspiration}

Daily $E_{s}$ below the wheat canopy was measured using micro-lysimeters (MLS). Each MLS consisted of an intact soil core collected in a PVC cylinder $0.20 \mathrm{~m}$ long $\times 0.11 \mathrm{~m}$ (outer diameter) with thick walls $(2.5 \mathrm{~mm})$. PVC was chosen to minimize heat conduction from the atmosphere to the soil within the core. Silos for inserting the MLS were carefully installed between the crop rows immediately after sowing in each of three replicates of TM and TN treatments. The purpose of the silos was to provide a location within the crop where $E_{s}$ could be regularly measured. For more details, see Balwinder-Singh et al. ${ }^{[12]}$ and Zhang et al. ${ }^{[41]}$

The soil in the MLS was measured and replaced immediately after each rainfall or irrigation event. Each MLS was weighed every morning at 7:00 using a digital field balanced with $0.001 \mathrm{~kg}$ precision, and then it was placed in a silo in an experimental plot. During the process care was taken to ensure no damage to the soil surface, the mulch layer in the MLS or the crop surrounding the silos.

The total seasonal $E T_{c}$ of winter wheat was calculated by using the soil water balance equation for the entire growing season as follows (Equation (8)):

$$
E T_{c}=I+P-\Delta S-R-D
$$

where, $I$ is irrigation amount, $\mathrm{mm} ; P$ is precipitation, $\mathrm{mm} ; \Delta S$ is the change in soil water storage, i.e., the difference between soil water content values at planting and end of the season; $R$ is the surface runoff $(\mathrm{mm})$, which was assumed to be zero because movement was inhibited by earth dikes; and $D$ is the deep percolation below the crop root zone $(\mathrm{mm})$ that was estimated using a recharge coefficient $(\alpha)$ multiplied by the depth of irrigation $(I, \mathrm{~mm})$ following Zhang et al. (Equation (9)) ${ }^{[42]}$.

$$
D=\alpha I
$$

where, the recharge coefficient $(\alpha)$ depends on soil texture and the irrigation depth. The coefficient ranges from 0.1 for clay soil to 0.3 for sandy soil. Values of $\alpha$ were taken to be 0.1 for total irrigation depth $\leq 90 \mathrm{~mm}, 0.15$ for depths between 90 and $250 \mathrm{~mm}$ and 0.2 for depths $\geq 250 \mathrm{~mm}$ for the soils in this experiment ${ }^{[42]}$.

\subsection{Statistical analysis}

ANOVA was determined for each experimental year and statistically significant differences among treatments were determined using the $F$-test. Differences among means for treatments were compared using Duncan's multiple range test (SPSS 10.0). A probability $(p)$ level of 0.05 was selected to test if differences were random.

\section{Results}

\subsection{Air and dew point temperature, relative humidity and soil temperature}

Figure 2 shows that the daily mean soil temperatures of TM0 and TN0 had a small degree of variability compared with TM1 and TN1 during the April-June growing stages. The TM0 for mulch-covered soil tended to have a slightly higher temperature than the non-mulched TN0 data during both seasons, except for June 2015. The soil temperatures were less variable than $T_{a}$ and they tended to be higher than $\mathrm{T}_{\mathrm{a}}$ during April and lower during late May and June. The daily mean TM0 was $1.13^{\circ} \mathrm{C}$ higher than TN0 during April-June 2014 (Table 2), and was $0.6^{\circ} \mathrm{C}$ higher than TN0 during April-June 2015 (Table 2). In both years, the $T_{a}$ at $15 \mathrm{~cm}$ height tended to fluctuate lower than soil temperatures during April and changed to fluctuate slightly higher than soil temperatures in late May and June. Overall, the daily mean TM0 was higher than TM1 during both seasons (Table 2). For TN, the daily mean difference between TN0 and TN1 was small (Table 2).

Table 2 Seasonal mean of daily temperature ${ }^{\dagger}$ and relative humidity from April to June in 2014 and 2015

\begin{tabular}{cccccccccc}
\hline \multirow{2}{*}{ Year } & \multicolumn{3}{c}{ Temperature $/{ }^{\circ} \mathrm{C}$} & & \multicolumn{4}{c}{ Relative humidity/\% } \\
\cline { 2 - 6 } \cline { 7 - 9 } & TM0 & TM1 & TN0 & TN1 & & TM-up & TM-dn & TN-up & TN-dn \\
\hline 2014 & 19.5 & 19.0 & 18.4 & 18.6 & 65.1 & 74.1 & 67.6 & 75.4 \\
2015 & 21.2 & 19.6 & 20.6 & 20.2 & & 61.5 & 70.4 & 60.9 & 70.7 \\
\hline
\end{tabular}

Note: ${ }^{\dagger}$ TM0 and TN0 are soil temperatures at $3 \mathrm{~cm}$ depth, TM1 and TN1 are air temperatures at $15 \mathrm{~cm}$ height. $\ddagger \mathrm{TM}$-up and $\mathrm{TN}$-up are relative humidity measurements at $30 \mathrm{~cm}$ above the canopy and TM-dn and TN-dn are relative humidity measurements at $15 \mathrm{~cm}$ above the soil.

For all days in April to mid-June, the near-surface daily mean RH for TM-dn and TN-dn was higher than that of TM-up and TN-up (Table 2). For the total daily mean RH during April to mid-June, the TM-dn and TN-dn were both $8 \%-10 \%$ higher than TM-up and TN-up, respectively, during both seasons.

Figure 3 presents the trend of mean daily $\mathrm{T}_{\mathrm{d}}$ above the canopy $\left(T M-D_{u p}\right.$ and $\left.T N-D_{u p}\right)$ and near-surface $\left(T M-D_{d n}\right.$ and $\left.T N-D_{d n}\right)$ from April to mid-June 2014 (Figure 3a) and 2015 (Figure 3b). The near-surface $T_{d}$ values were always $1.2^{\circ} \mathrm{C}-2.5^{\circ} \mathrm{C}$ higher than the above-canopy temperatures for both $\mathrm{TM}$ and $\mathrm{TN}$ during the main growing season. This was expected because $T$ was occurring in the canopy. Figure 3 shows that there was little difference in $T_{d}$ values for the above-canopy $T M-D_{\text {up }}$ and $T N-D_{\text {up }}$ data throughout both seasons. The near-surface $T_{d}$ values, however, did differ between TM and TN. The $T_{d}$ values for TN-D $\mathrm{D}_{\mathrm{dn}}$ were generally higher than the $T M-D_{d n}$ values, especially during April or June, when the $T N-D_{d n}$ dew points were clearly higher than the TM- $D_{d n}$ values. 

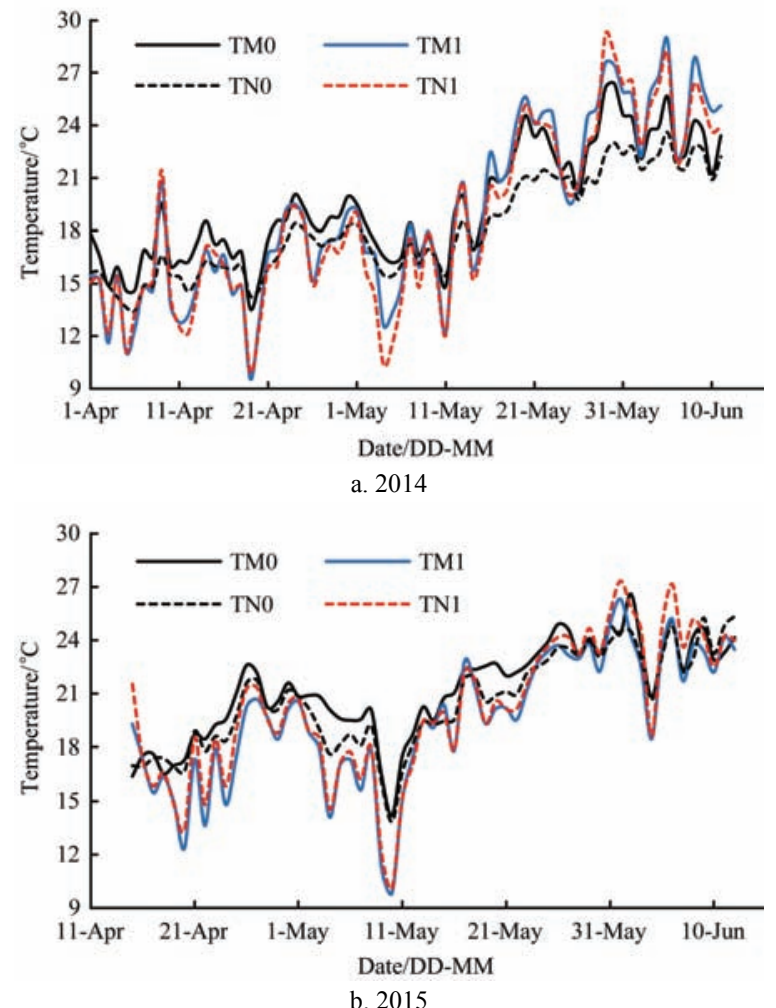

Note: TM0 and TN0 represent the soil temperatures at $3 \mathrm{~cm}$ depth with mulched and non-mulched treatments respectively, and the TM1 and TN1 represent the air temperatures at $15 \mathrm{~cm}$ height with mulched and non-mulched treatments respectively.

Figure 2 Daily mean soil temperatures at $3 \mathrm{~cm}$ depth and air temperatures at $15 \mathrm{~cm}$ height for (a) 2014 and (b) 2015
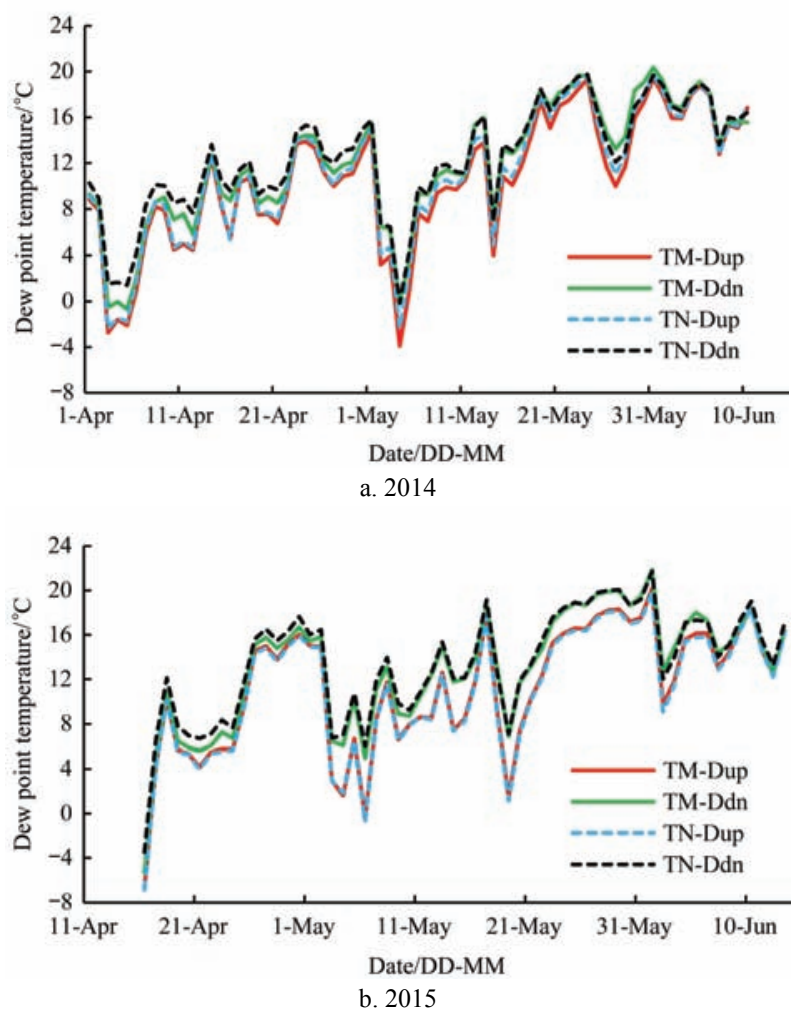

Note: The TM-Dup and TN-Dup represent the dew point temperature at a height of $30 \mathrm{~cm}$ above the wheat canopy for mulched and non-mulched treatments respectively. The TM-Ddn and TN-Ddn represent the dew point temperature at a height of $15 \mathrm{~cm}$ above the soil surface for mulched and non-mulched treatments respectively.

Figure 3 Mean daily TM and TN dew point temperature comparison in 2014 and 2015

\subsection{Effects of mulching on the turbulent exchange coefficient}

The air turbulent exchange creates an increase in the vertical and horizontal exchange and transfer of $\lambda E$ and $H$ in the atmosphere. In this study, the turbulent exchange coefficient $(K)$ values above-canopy and within-canopy were both calculated. Figure 4 shows that the daily above-canopy $K$ value had large fluctuations during the main growing season (April-June) for both TM and TN treatments. The daily mean $K$ values appeared high, especially in April, and they decreased above $20 \%$ later in the season. From April to mid-June 2014, the daily mean K values for $\mathrm{TM}-\mathrm{K}_{\mathrm{up}}$ were higher than for $\mathrm{TN}-\mathrm{K}_{\mathrm{up}}$ (Table 3).
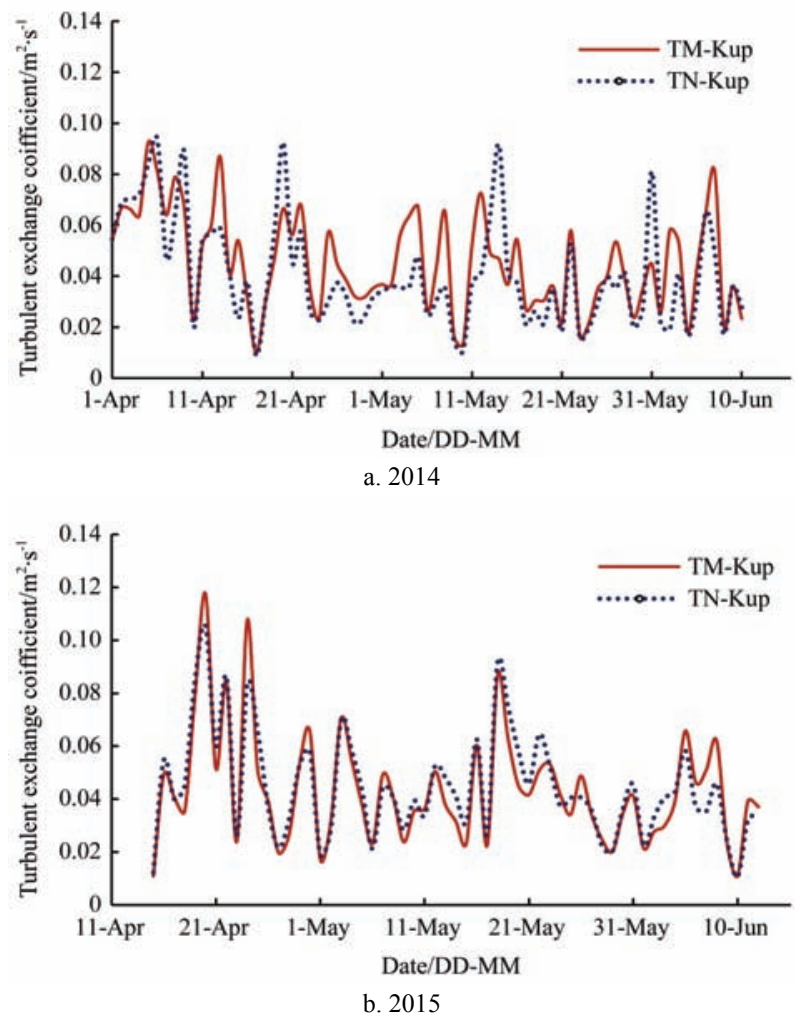

Note: TM-K $\mathrm{K}_{\text {up }}$ and $\mathrm{TN}-\mathrm{K}_{\text {up }}$ represent the $\mathrm{K}$ values above canopy for mulched and non-mulched treatments respectively.

Figure 4 Mean daily K of TM and TN (above canopy) in 2014 and 2015

Table 3 Seasonal mean of dailyK values from April to mid-June in 2014 and 2015

\begin{tabular}{cccc}
\hline Treatment & 2014 above canopy & 2015 above canopy & 2015 near surface \\
\hline TM & 0.046 & 0.044 & 0.033 \\
TN & 0.041 & 0.044 & 0.027 \\
\hline
\end{tabular}

In Figure 5 and Table 3, the above-canopy daily mean $K$ values $\mathrm{TM}-\mathrm{K}_{\text {up }}$ and $\mathrm{TN}-\mathrm{K}_{\text {up }}$ were higher than the near-surface $\mathrm{TM}-\mathrm{K}_{\mathrm{dn}}$ or TN-K $\mathrm{K}_{\mathrm{dn}}$ values, respectively, for most days in 2015 , and mulching increased the near-surface $K$ value relative to TN (Table 3).

\subsection{Energy flux trends}

Figure 6 presents trends of half-hourly energy balance data for the mulched treatment during April to mid-June 2015. $R_{n}$ was partitioned to the other three energy fluxes and, during daylight hours, $\lambda E$ consumed the most energy. However, more energy was partitioned to sensible than to latent heat flux during the senescence period in June when crop evapotranspiration declined. The $\lambda E$ values were typically higher than $R_{n}$ and $H$ was negative from the late afternoon through the night (typically from 5:00PM to 6:00AM). During daylight hours, $\lambda E$ and $H$ 
were mostly positive, with the $H$ values increasingly positive during June. The $G$ value was always small and stable compared with other energy fluxes.
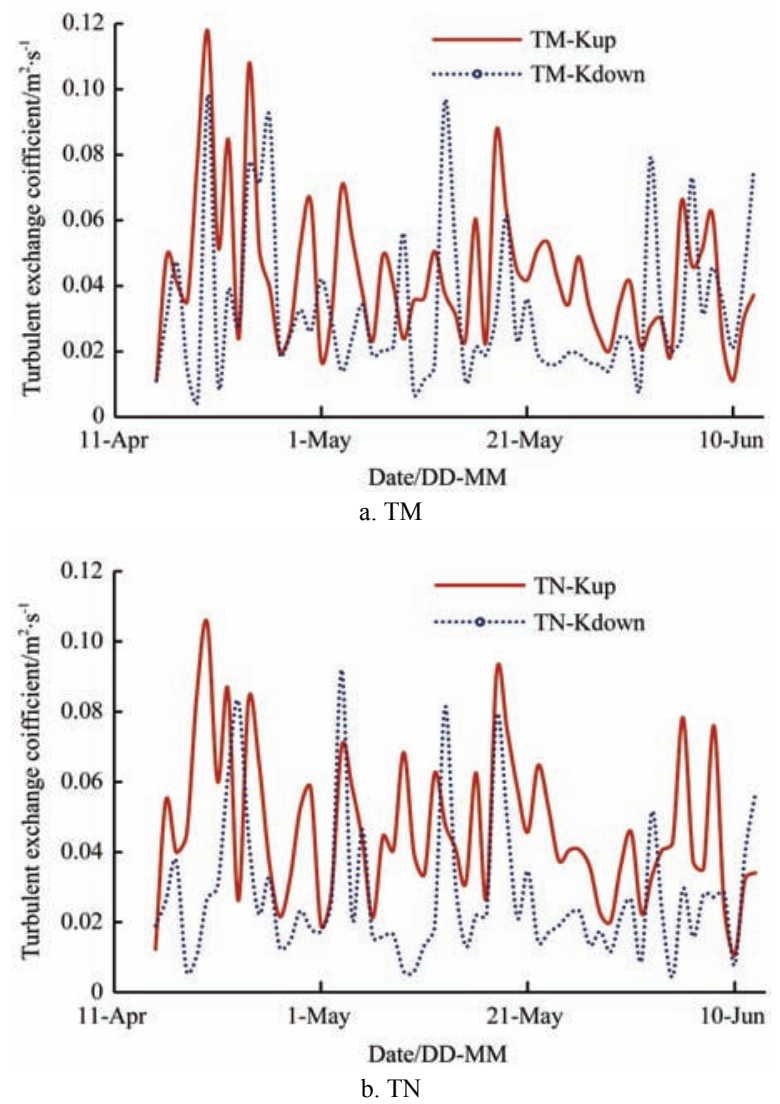

Note: The TM-Kdn represents the $K$ values canopy and within canopy for mulched treatments. The TN-Kdn represents the $K$ values within canopy for non-mulched treatments.

Figure 5 Mean daily $K$ of TM and TN above canopy and near-surface in 2015

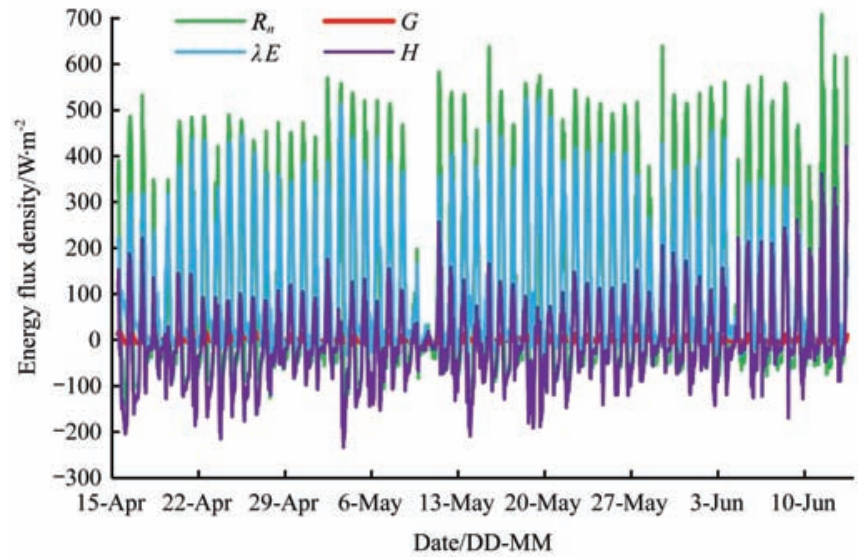

Figure 6 Trend of the four energy balance components for TM during the 2015 main growing season

Figure 7 presents three examples of diurnal curves of the four energy fluxes of TM (i.e., over mulched soil) that represent three different growth stages of the winter wheat. The left-hand panel depicts the recovering growth stage (i.e., following winter), with relatively low evapotranspiration. The middle panel represents the stem-elongation stage, and $H$ is generally low and positive during the day, but may become negative in late afternoon. The right-hand panel depicts the senescence period, which is associated with lower but still appreciable $\lambda E$ and higher $H$ compared to the middle panel.
Figure 8 shows the comparison of differences between the non-mulched and mulched treatment for mean daily energy balance components. The TN-TM values for $G$ were slightly negative during April and near zero during the remainder of the season, so there was only a small mulching effect on $G$ before the canopy developed. The TN-TM values for $R_{n}$ were variable but mostly positive during the recovering growth period, quite close to zero during the stem-elongation period and became increasingly negative during senescence. This implies that $R_{n}$ was higher over the TN during the recovering period when the plants were small; the difference decreased to near zero during the period when the plant canopy dominated the energy balance; and the $R_{n}$ was higher over the mulched treatment when the plant canopy was senescing and transpiring less. The TN-TM values for $H$ followed a similar trend as $R_{n}$. The TN had more "upward" positive $H$ than the mulched treatment during the recovering period, whereas there was little difference during stem elongation. The mulched treatment had more positive $H$ than the TN during senescence when the fields were more exposed to radiation and wind. Finally, the TN-TM values for $\lambda E$ followed $R_{n}$ during the recovering and stem-elongation periods, but then deviated $R_{n}$ differences during senescence.
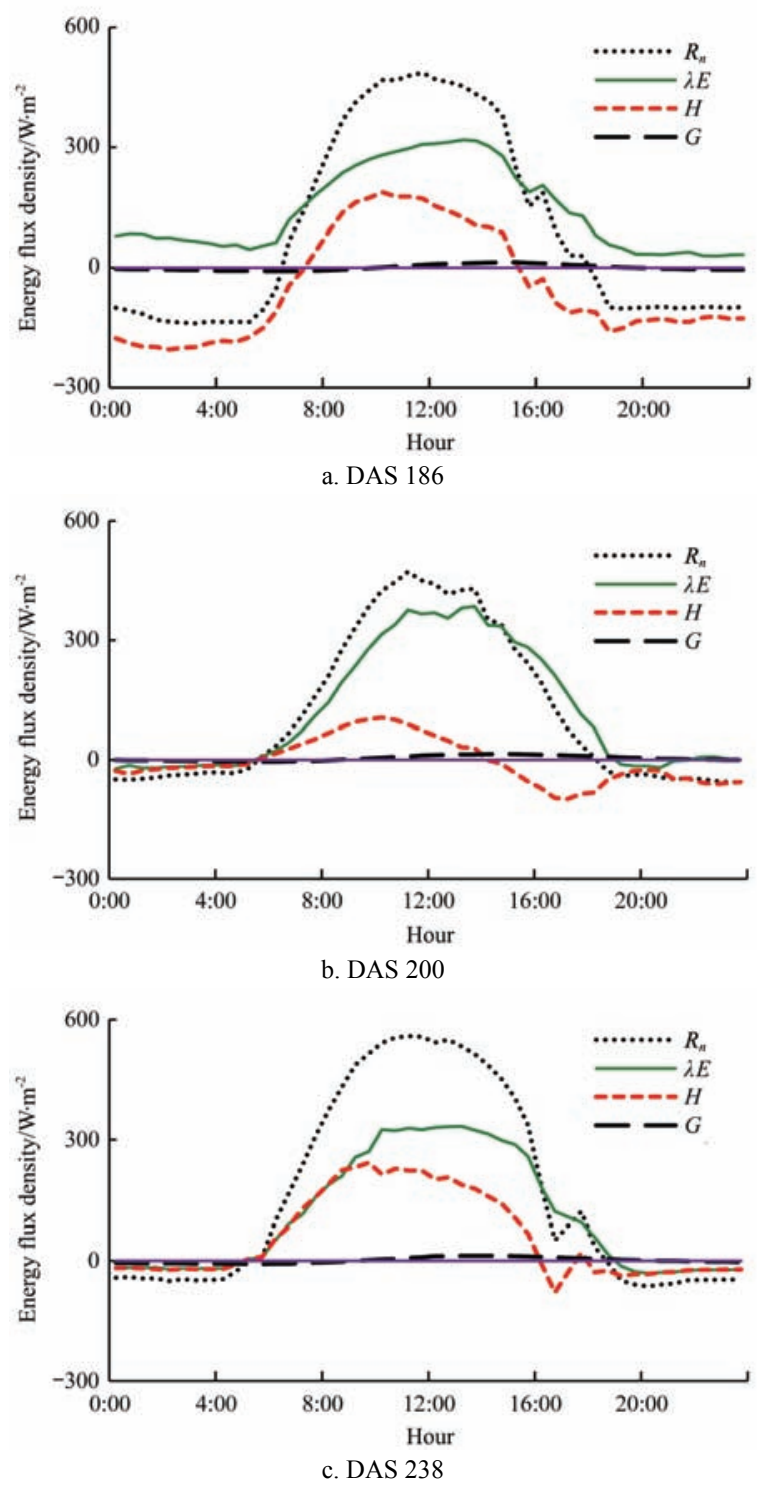

Figure 7 Sample diurnal curves for the four energy flux density of

TM during recovering growth (27 April; DAS 186), stem-elongation growth (11 May; DAS 200), and scenescence (19 June; DAS 238) in 2015 


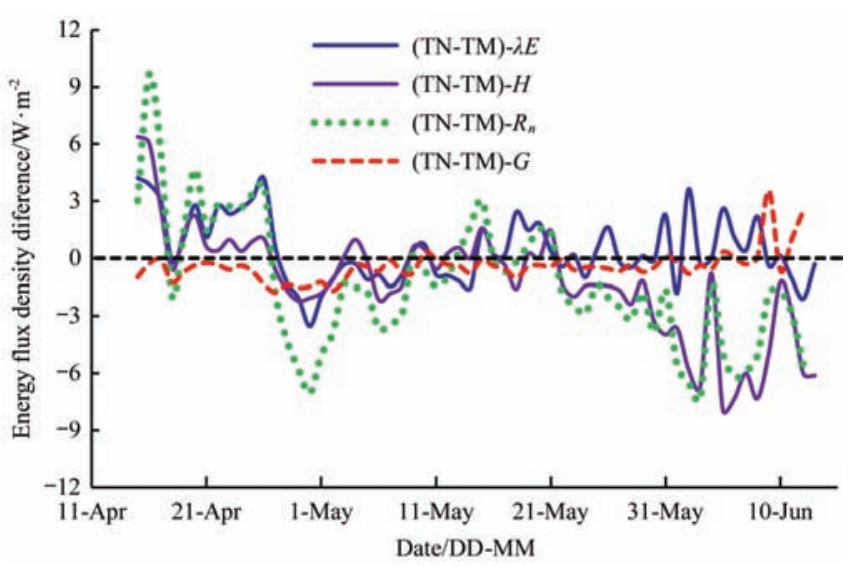

Figure 8 Mean daily difference of four energy flux density between TN and TM during the 2015 growing season

3.4 The relationship between sensible heat flux and air temperature

$H$ had a close relationship with the $T_{a}$ difference gradient,

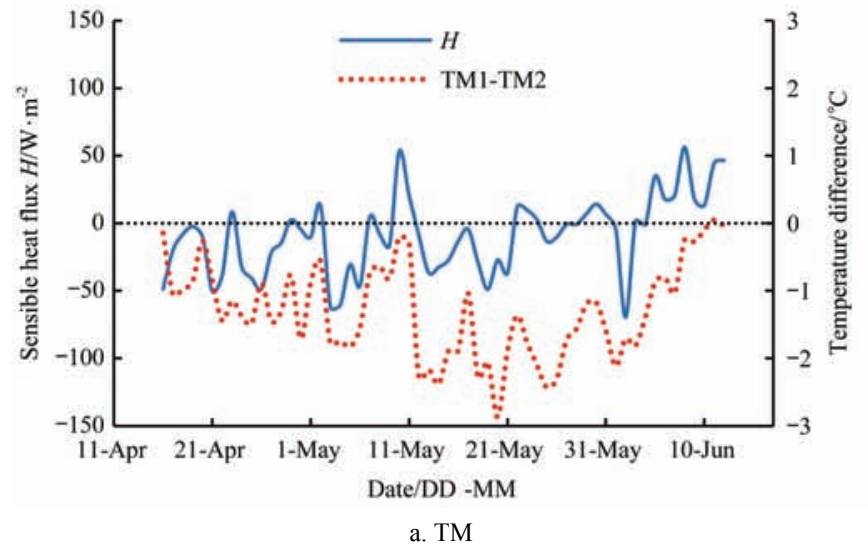

which determines the direction of $H$. If temperature of the air aloft is higher than the temperature expected and the air near the surface was adiabatically lifted, then turbulence can cause downward $H$ and provide additional energy for vaporization. For any given turbulence level, the bigger the difference in the real and expected $T_{a}$ aloft is, the greater the downward $H$ would be. In this study, $T_{a}$ values above the canopy (TM2 and TN2) and at $15 \mathrm{~cm}$ above the soil surface (TM1 and TN1) were measured every 15 min to investigate how temperature profile change with $H$ data.

Figure 9 presents the relationship between $H$ and $T_{a}$ difference of TM1 and TM2, and $T_{a}$ difference of TN1 and TN2, respectively, during 2015. For both TM1 minus TM2 and TN1 minus TN2, the differences were negative for most days, which implied that the above-canopy $T_{a}$ was higher than that within-canopy for both treatments. While the general pattern of the temperature differences in Figure 9a and Figure 9b were similar to the pattern of the trend in $\mathrm{H}$, there are differences because $\mathrm{H}$ was affected by canopy roughness, wind speed, etc., in addition to the temperature profile.

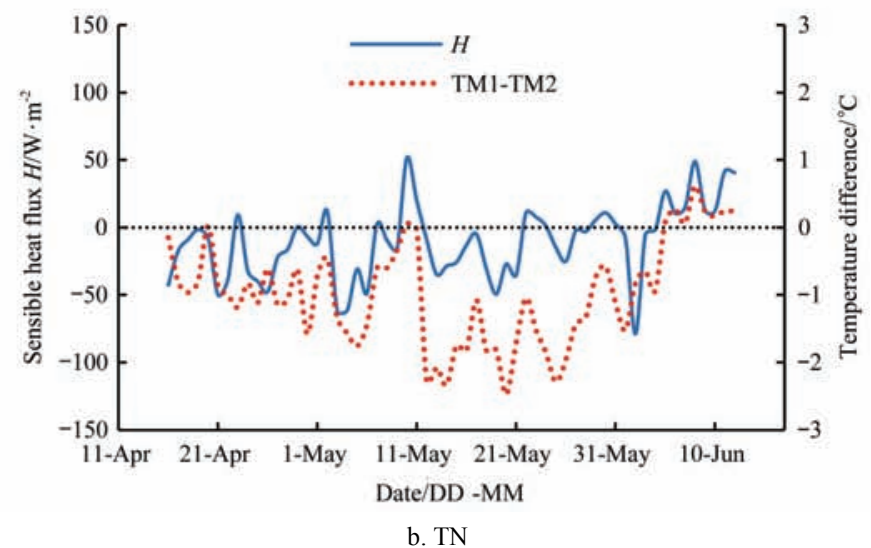

Figure 9 Trends of $\mathrm{H}$ and $T_{a}$ difference (TM1-TM2) and difference of TN1 and TN2 over the mulched treatment in 2015

The linear functional relationship between $H$ and $T_{a}$ difference between canopy down and canopy up $\left(T_{c d}-T_{c u}\right)$ was established (Figure 10), based on the data from all TM and TN treatments, i.e. $H=19.27\left(T_{c d}-T_{c u}\right)+12.52$. Although the coefficient of determination was only $R^{2}=0.29$, considering $H$ was affected by several parameters, $H$ had exhibited a good relationship with the above- and near-canopy $T_{a}$.

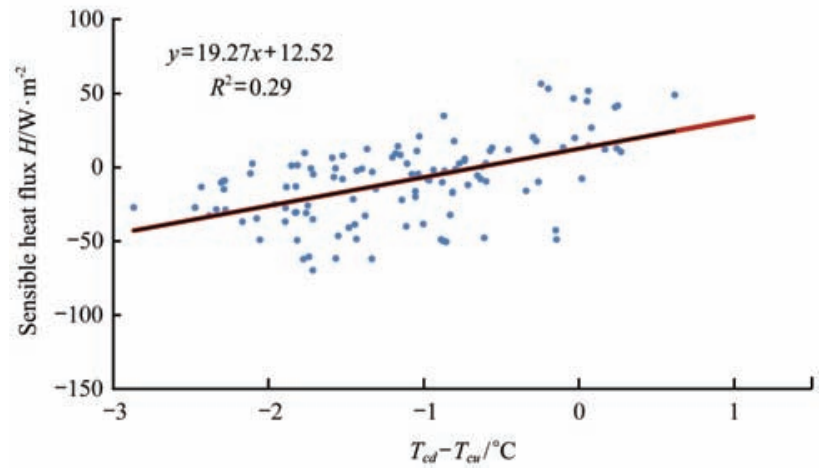

Figure 10 Linear relationship of $\mathrm{H}$ with $T_{a}$ difference between the air temperature at canopy down $\left(T_{c d}\right)$ and the air temperature up the canopy $\left(T_{c u}\right)$

\subsection{Soil evaporation and crop evapotranspiration}

The daily crop evapotranspiration $\left(\mathrm{ET}_{\mathrm{pmd}}\right)$ was attained by dividing $\lambda E$, in $\mathrm{MJ} / \mathrm{m}^{2}$ per unit time, by $\lambda=2.45 \mathrm{MJ} / \mathrm{kg}$ (Equation
(2)). Figure 11 shows the trend in $E_{s}$ measured with the MLS and $\mathrm{ET}_{\text {pmd }}$ estimated with the Penman-Monteith equation over TM and $\mathrm{TN}$. Figure 11 shows nearly identical $\mathrm{ET}_{\mathrm{pmd}}$ for $\mathrm{TM}$ and $\mathrm{TN}$ treatments in 2015 but slightly lower $\mathrm{ET}_{\text {pmd }}$ for $\mathrm{TN}$ treatment in 2014. The $E_{s}$ trend seemed relatively unrelated to the $\mathrm{ET}_{\mathrm{pmd}}$ during both years. The mean $\mathrm{E}_{\mathrm{s}} / \mathrm{ET}_{\mathrm{pmd}}$ ratios were calculated by treatment and year (Table 4), and the results indicated that $\mathrm{E}_{\mathrm{s}} / \mathrm{ET}_{\mathrm{pmd}}$ was generally higher for TN.

During the 2014 season, the mean daily $E_{s}$ was $0.78 \mathrm{~mm} / \mathrm{d}$ for $\mathrm{TM}$ and $1.28 \mathrm{~mm} / \mathrm{d}$ for TN, so the mean daily $E_{s}$ was reduced by $39 \%$ by mulching. During the 2015 season, the mean daily $E_{s}$ was $0.89 \mathrm{~mm} / \mathrm{d}$ for TM and $1.13 \mathrm{~mm} / \mathrm{d}$ for TN, so the mean daily $E_{s}$ was reduced by $21 \%$ by mulching. The daily crop $\mathrm{ET}_{\mathrm{pmd}}$ for $\mathrm{TM}$ and $\mathrm{TN}$, however, showed little difference in either year. $\mathrm{ET}_{\mathrm{pmd}}$ was reduced on days with rainfall (Figure 11), as expected. For example, the $\mathrm{ET}_{\mathrm{pmd}}$ decreased sharply on May 10, 2015, when $22 \mathrm{~mm}$ of precipitation occurred.

As shown in Table 4, daily average $E_{s}$ for TM constituted about $19 \%$ of $\mathrm{ET}_{\mathrm{pmd}}$ for the stem-elongation and heading stages of winter wheat and $\mathrm{ET}_{\mathrm{pmd}}$ was mostly used for $T$. During the grain-filling and senescence stage, the mulched treatment $\mathrm{E}_{\mathrm{s}} / \mathrm{ET}_{\mathrm{pmd}}$ increased to about $26 \%$ mainly due to the decrease in crop $T$. The mean $\mathrm{TN} \mathrm{E}_{\mathrm{s}} / \mathrm{ET}_{\mathrm{pmd}}$ was about $28 \%$ during the stem-elongation and heading stages, and the ratio increased to about $34 \%$ during the grain-filling (senescence) period. 

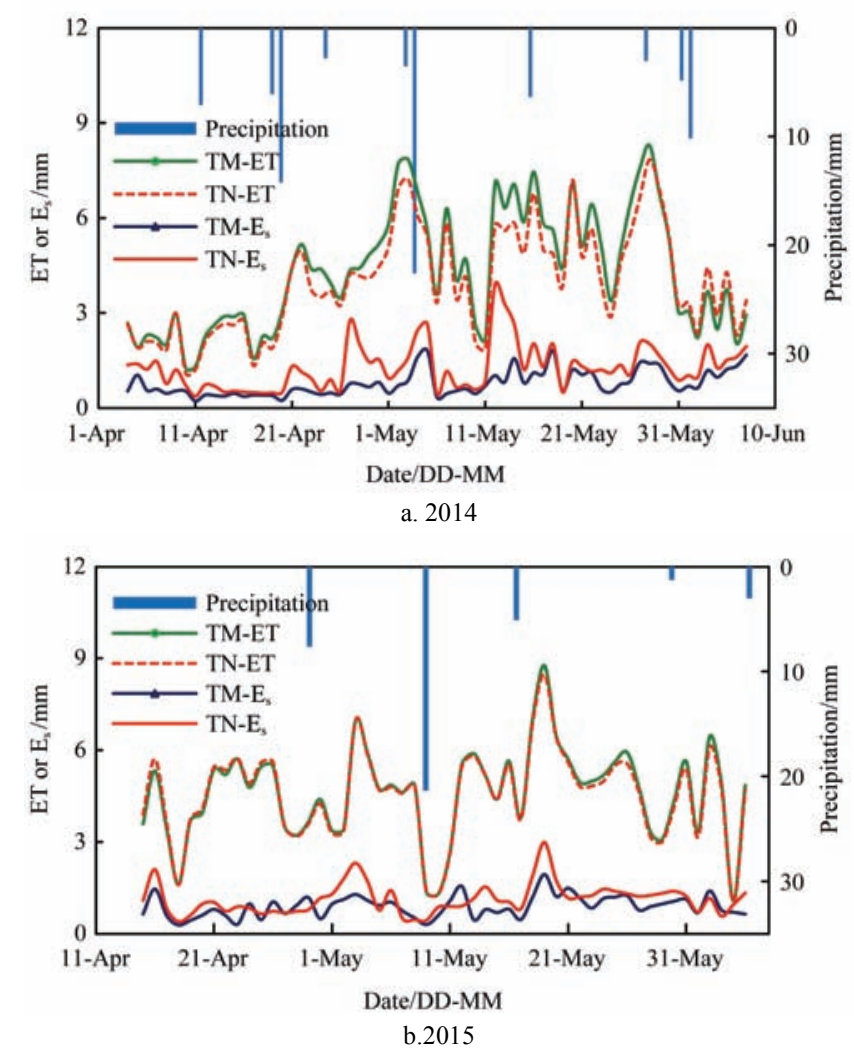

Note: The TM-ET and TN-ET represent the daily crop evapotranspiration for mulched and non-mulched treatments respectively, and the $\mathrm{TM}-\mathrm{E}_{\mathrm{s}}$ and $\mathrm{TN}-\mathrm{E}_{\mathrm{s}}$ represent the daily soil evaporation for mulched and non-mulched treatments respectively.

Figure 11 Trends in daily $\mathrm{E}_{\mathrm{s}}$ and $\mathrm{ET}_{\mathrm{pmd}}$ for mulched (TM) and no-mulched (TN) treatments during (a) 2014 and (b) 2015

Table 4 Mean $\mathrm{E}_{\mathrm{s}} / \mathrm{ET}_{\text {pmd }}$ ratios (\%) during 2014 and 2015 for TM and TN treatments

\begin{tabular}{|c|c|c|c|c|c|c|}
\hline \multirow{3}{*}{ Treatment } & \multicolumn{6}{|c|}{ Growth stage } \\
\hline & \multicolumn{2}{|c|}{ Stem-elongation } & \multicolumn{2}{|c|}{ Heading } & \multicolumn{2}{|c|}{ Grain-filling } \\
\hline & 2014 & 2015 & 2014 & 2015 & 2014 & 2015 \\
\hline $\mathrm{TM}$ & 19 & 19 & 17 & 21 & 27 & 25 \\
\hline $\mathrm{TN}$ & 36 & 24 & 31 & 26 & 36 & 32 \\
\hline
\end{tabular}

\section{Discussion}

Soil temperature depends on solar radiation, and low solar radiation during winter months diminishes differences between temperatures under mulched and no-mulch soils. Since mulch also blocks the loss of long-wave radiation from soil, one would expect the non-mulched soil to cool more than the mulched soil during the long winter nights. Therefore, mulching reduced long-wave radiation losses during long winter nights and resulted in higher temperatures for the mulched soil in April. Since the mulched soil was warmer than the non-mulched soil during most of April to mid-June in both seasons, the mulch seemed to improve heat conditions of the soil during spring growth; which agrees well with the report by Chen and Zhang ${ }^{[17]}$. In both years, $T_{a}$ at $15 \mathrm{~cm}$ height tended to fluctuate slightly above the soil temperatures in late May and June. During that period, the crop T decreased and more incoming energy was partitioned to sensible heat rather than to latent heat, which increased $T_{a}$.

Although there is an obvious difference in $R H$ between above-canopy and within-canopy for TM and TN treatments, this study's results did not identify $R H$ differences between TM-up and
TN-up or between TM-dn and TN-dn, which indicates mulching had no obvious effect on the RH measurements over the winter wheat field. The near-surface $T_{d}$ values did differ between TM and TN during April and June, but this difference diminished during May (Figure 3) as the canopy reached full cover. Most likely, mulching blocked some of the incoming solar radiation from reaching the soil when the LAI was small, so there was less energy for vaporization of water in the mulched soil.

The daily mean $K$ values for TM were higher than for TN (Table 3), which implies that mulching improved $\mathrm{K}$ to some extent. The daily mean $K$ values above-canopy were higher than the near-surface values, and it is possible that the difference was mainly because the near-surface measurements were collected close to or within the canopy, whereas the weather parameters (e.g., solar radiation and wind speed) were not measured directly over the canopy. Differences in the atmospheric conditions above and within a canopy can deeply affect the air turbulent exchange activity. In addition, the straw mulching might decrease the heat and soil water exchange activity between the surface soil and air, which resulted in the enhancement of $K$ above the mulched straw. This could help to increase both latent and sensible heat fluxes.

Mulching clearly affects field energy distribution, which in turn has an impact on crop growth and yield. In this study, it was found that $\lambda E$ consumed most of the incoming energy, and the crop growth stages had a close relationship with the energy distribution. When the plants and canopy were small or during the senescence period, less water was vaporized and more incoming energy contributed to heating the surface and air. When $H$ became negative, this implied that part of the energy contributing to $\lambda E$ was provided by sensible heat transfer in addition to net radiation $\left(R_{n}\right)$. Negative $H$ was an indication of advection, where $\lambda E$ can exceed $R_{n}$ (in accord with the observations of Rosa et al. ${ }^{[43]}$ in a cotton field, indicating that the $T_{a}$ aloft was higher than expected if air was adiabatically lifted from the surface (Figure 9).

It seemed that the $\mathrm{TN}$ tended to have slightly higher $\lambda E$ during the recovering period, which was most likely due to the TN soil having more exposure to radiation and wind. There was little difference between TM and TN treatments during stem elongation because the canopy dominated the energy balance with little impact from the soil surface on the overall energy balance. During the senescence period, the $\lambda E$ was decreasing for both treatments because the plants were aging and $T$ was declining. Because the soil was dry during senescence and $T$ was low for both treatments, there was little difference in $\lambda E$ for $\mathrm{TN}$ and $\mathrm{TM}$ during the senescence period.

A clear difference was found in $E_{s}$ for TM and TN treatments, and mean daily $E_{s}$ was reduced by $21 \%-39 \%$ during the two seasons under straw mulching. $\mathrm{E}_{\mathrm{s}} / \mathrm{ET}_{\mathrm{pmd}}$ was generally higher for $\mathrm{TN}$, which is in agreement with other studies ${ }^{[17,41,44]}$. The daily crop $\mathrm{ET}_{\mathrm{pmd}}$ for $\mathrm{TM}$ and $\mathrm{TN}$, however, showed little difference in either year. This revealed that TM decreased $E_{s}$, but increased crop $T$ to maintain about the same level of $\mathrm{ET}_{\mathrm{pmd}}$; this also indicated that the seasonal $E T_{c}$ of winter wheat would not have obvious differences between $\mathrm{TM}$ and $\mathrm{TN}$ treatments. The conclusion was verified and shown in Table 5. TM decreased total irrigation about 7\%-15\% compared with $\mathrm{TN}$, but there were no significant differences $(p>0.05)$ in cumulative $E T_{c}$. Most likely, straw mulching decreased $E_{s}$, which may result in the transfer of considerably more soil water for plant $\mathrm{T}$. This would increase crop transpiration $\mathrm{T}$ and decrease the $T$ efficiency for TM treatment; however, this deduction needs further verification. 
Table 5 Number of irrigation events, irrigation amount $(I)$, precipitation $(P)$, change in soil water storage $(\Delta S)$, deep percolation $(D)$ and crop evapotranspiration $\left(E T_{c}\right)$ during 2013-2015 whole seasons of winter wheat

\begin{tabular}{|c|c|c|c|c|c|c|}
\hline Treatment & $\begin{array}{l}\text { Irrigation amount } I \\
/ \mathrm{mm}\end{array}$ & $\begin{array}{l}\text { Number of } \\
\text { irrigations }\end{array}$ & $\begin{array}{l}\text { Precipitation } P \\
/ \mathrm{mm}\end{array}$ & $\begin{array}{c}\text { Soil water } \\
\text { storage change } \Delta S / \mathrm{mm}\end{array}$ & $\begin{array}{l}\text { Downward flux } D \\
/ \mathrm{mm}\end{array}$ & $\begin{array}{l}E T_{c} \\
/ \mathrm{mm}\end{array}$ \\
\hline \multicolumn{7}{|c|}{$2013.10-2014.6$} \\
\hline $\mathrm{TN}$ & $262 \mathrm{a}$ & 6 & 104 & -51 & 33 & $384 a$ \\
\hline \multicolumn{7}{|c|}{$2014.10-2015.6$} \\
\hline $\mathrm{TM}$ & $249 \mathrm{a}$ & 5 & 111 & -51 & 34 & $377 \mathrm{a}$ \\
\hline $\mathrm{TN}$ & $294 b$ & 6 & 111 & -23 & 38 & $390 \mathrm{a}$ \\
\hline
\end{tabular}

Note: The number of irrigation events and irrigation amounts for all treatments consisted of pre-sowing irrigation and irrigation during the April to June growing season. The second and seventh column means in the same year followed by the same letter are not significantly different $(p>0.05)$.

The results also indicate that, if an adequate irrigation schedule is adopted along with the advanced drip irrigation method, straw mulching is unlikely to significantly decrease crop $E T_{c}$, and will not be the best solution for the management of the reduced groundwater in NCP. Further study on the impact of deficit irrigation scheduling in combination with efficient water-saving irrigation is needed to assess the benefits of those practices.

\section{Conclusions}

Based on field experimental results during 2013-2015 for winter wheat, it was concluded that the presence of mulch altered the soil temperature, and improved the near-surface $T_{a}$ compared to TN from April to June in NCP. Mulching had no significant effect on RH compared with TN.

Straw mulching increased $\mathrm{K}$ to some extent, and the $\mathrm{K}$ value under the canopy was higher than that above the canopy for all treatments. For most hours from 5:00 PM to 6:00 AM during April-June, $\lambda E$ was higher than $R_{n}$, and $H$ was negative and part of the energy needed for evapotranspiration was provided by transfer from the warmer air aloft. The straw mulch had little effect on the seasonal trends for $G$ and $\lambda E$ energy flux distribution, but the TN-TM values for $R_{n}$ and $H$ were slightly positive during the recovery period and slightly negative during the senescence period. The $R_{n}$ and $H$ deviations for TM and TN treatments were likely due to the changes in albedo and the transition to higher air and surface temperature during the recovery and senescence periods.

Straw mulching decreased $E_{s}$ but increased crop $T$, so there was no significant effect on the seasonal $E T_{c}$. The results indicate that mulching do not decrease $E T_{c}$ of adequately drip-irrigated winter wheat, and the practice will not provide optimal benefits for management of the declining groundwater in NCP, or in other parts of the world with similar problems - if adequate drip irrigation system is used.

\section{Acknowledgements}

We acknowledge that this work was financially supported by the National "12th Five-Year Plan" Scientific and Technological Project of China (2014BAD12B05) and the IWHR Innovative Team Project (ID0145B602017). In addition, we thank Elaine Monaghan, BSc (Econ), from Liwen Bianji, Edanz Group China (www.liwenbianji.cn/ac), for editing the English text of this manuscript.

\section{[References]}

[1] Liu X Y, Lin E D. Impact of climate change on water requirement of main crops in North China. Journal of Hydraulic Engineering, 2004; 2: 77-82. (in Chinese)
[2] Zhang X, Pei D, Hu C. Conserving groundwater for irrigation in the North China Plain. Irrg Sci, 2003; 21: 159-166.

[3] Liu C M, Zhang X Y, Zhang Y Q. Determination of daily evaporation and evapotranspiration of winter wheat and maize by large-scale weighing lysimeter and micro-lysimeter. Agricultural and Forest Meteorology, 2002; 111: 109-120.

[4] Li J M, Inanaga S, Li Zh, Egrinya E A. Optimizing irrigation scheduling for winter wheat in the North China Plain. Agricultural Water Management, 2005; 76: 8-23.

[5] Pereira L S. Higher performances through combined improvements in irrigation methods and scheduling: a discussion. Agric Water Manage, 1999; 40(2): 153-169.

[6] Pereira L S, Goncalves J M, Dong B. Assessing basin irrigation and scheduling strategies for saving irrigation water and controlling salinity in the upper Yellow River Basin, China. Agric Water Manage, 2007; 93: $109-122$.

[7] Wang J D, Gong S, Xu D. Impact of drip and level-basin irrigation on growth and yield of winter wheat in the North China Plain. Irrigation science, 2013; 31: 1025-1037.

[8] Wang J D, Gong S, Gao Z. Effects of drip irrigation mode on spatial distribution of soil water and nitrate and winter wheat yield. Transactions of the CSAE, 2009; 25(11): 67-72. (in Chinese)

[9] Wang J D, Gong S, Sui J. Effects of drip irrigation frequency on the farmland soil water-heat distribution and spring maize growth in North China. Transactions of the CSAE, 2008; 24(2): 39-4. (in Chinese)

[10] Zhang H P, Theib Y O, Sonia G. Water-use efficiency and transpiration efficiency of wheat under rain-fed conditions and supplemental irrigation in a Mediterranean-type environment. Plant Soil, 1998; 201: 295-305.

[11] Sun H Y, Liu C M, Zhang X Y. Effects of irrigation on water balance, yield and WUE of winter wheat in the North China Plain. Agric Water Manage, 2006; 85: 211-218.

[12] Zhang Y Q, Wang J D, Gong S. Measuring and modeling of soil evaporation for winter wheat with drip irrigation (in Chinese). Transactions of the CSAE, 2014; 30(7): 91-98.

[13] Unger P W. Straw-mulch rate effect on soil water storage and sorghum yield. Soil Science Society of America Journal, 1978; 42: 486-491.

[14] Limon-Otetga A, Sayre K D, Francis C A. Wheat and maize yields in response to straw management and nitrogen under a bed planting system. Agronomy Journal, 2000; 92: 295-302.

[15] Zhang X Y, Chen S Y, Liu M Y. Improved water use efficiency associated with cultivars and agronomic management in the North China Plain. Agronomy Journal, 2005; 97: 783-790.

[16] Nath J C, Sarma R. Effect of organic mulches on growth and yield of Assam lemon (Citrus limon Burm.). Horticultural Research, 1992; 5: 19-23.

[17] Chen S Y, Zhang X Y, Pei D. Effects of straw mulching on soil temperature, evaporation and yield of winter wheat: field experiments on the North China Plain. Ann Appl Biol, 2007; 150: 261-268.

[18] Wicks G A, Crutchfield D A, Burnside O C. Influence of wheat (Triticum aestivum) straw mulch and metolachlor on corn (Zea mays) growth and yield. Weed Science, 1994; 42: 141-147.

[19] Shen J Y, Zhao D D, Han H F, Zhou X B, Li Q Q. Effects of straw mulching on water consumption characteristics and yield of different types of summer maize plants. Plant soil environ, 2012; 58 (4): 161-166

[20] Zhang P, Wei T, Wang H, Wang M, Meng X P, Mou S, et al. Effects of straw mulch on soil water and winter wheat production in dryland farming. Sci. Rep, 2015; 5, 10725, doi: 10.1038 /srep10725. 
[21] Tolk J A, Howell T A, Evett S R. Effect of mulch, irrigation, and soil type on water use and yield of maize. Soil. Tillage Research, 1999; 50: 137-147.

[22] Li Q, Chen Y H, Liu M Y. Effects of irrigation and straw mulching on microclimate characteristics and water use efficiency of winter wheat in North China. Plant Prod Sci, 2015; 11(2): 161-170.

[23] Cai J B, Liu Y, Xu D, Pereira L S. Simulation of the soil water balance of wheat using daily weather forecast messages to estimate the reference evapotranspiration. Hydrol Earth Syst Sci, 2009; 13: 1045-1059.

[24] Chen Y M, Guo G, Wang G X. Main crop water requirement and irrigation of China. Water Power Press Beijing, 1995. (in Chinese)

[25] Shi B. Experimental study on crop water stress detecting and irrigation index. China Institute of Water Resources and Hydropower Research, Beijing, 2006. (in Chinese)

[26] Monteith J L. Evaporation and environment. In: Fogg G.E. (Ed.). The state and movement of water in living organisms. Symposium of the Society for Experimental Biology, 1965; 19: 205-234.

[27] Allen R G, Pereira L S, Raes D, Smith M. Crop evapotranspiration guidelines for computing crop water requirements. FAO Irrigation and Drainage Paper No. 56, United Nations-Food and Agricultural Organization, Rome, Italy, 300p, 1998.

[28] Allen R G, Jensen M E, Wright J L, Burman R D. Operational estimates of reference evapotranspiration. Agron.J, 1989; 81: 650-662.

[29] Plate E J. Aerodynamic characteristics of atmospheric boundary layers. AEC Critical Review Series. Atomic Energy Commission, Div. Tech. Info. U.S.Gov. Print. Office, Washington, DC, 1971.

[30] Monteinth J L. Evaporation and surface temperature. Q. J. R. Meterol. Soc, 1981; 107: 1-27.

[31] Brutsaert W H. Evaporation into the atmosphere: Theory, history and applications. D.Reidel Publ. Co., Boston, MA, 1982.

[32] Allen R G, Pruitt W O, Wright J L, Howell T A, Ventura F, Snyder R, Itenfisu D, Steduto P, Berengena J, Baselga Yrisarry J, Smith M, Pereira L S, Raes D, Perrier A, Alves I, Walter I, Elliott R A. Recommendation on standardized surface resistance for hourly calculation of reference ETo by the FAO56 Penman-Monteith method. Agricultural Water Management, 2006; 81(1-2): 1-22.

[33] Stewart J B. On the use of the Penman-Monteith equation for determining areal evapotranspiration. In: Black T A, Spittlehouse D L, Novak M D, Price D T, (Eds.), Estimation of Areal Evapotranspiration,
IAHS Publisher No. 177, pp 3-12, 1989.

[34] Price D T, Black T A. Estimation of forest transpiration and $\mathrm{CO}_{2}$ uptake using the Penman-Monteith equation and a physiological photosynthesis model. In: Black T A, Spittlehouse D A, Novak M. D, Price D T (Eds.), Estimation of Areal Evapotranspiration, IAHS Publisher No. 177, pp 213-227, 1989.

[35] Allen R G, Pruitt W O, Businger J A, Fritschen L J, Jensen M E, Quinn F H. Evaporation and transpiration. In: Wootton et al. (Eds.), ASCE Handbook of Hydrology. New York, NY, Chapter 4, pp 125-252, 1996.

[36] Ben-Mehrez M, Taconet O, Vidal-Madjar D, Valencogne C. Estimation of stomatal resistance and canopy evaporation during the HAPEX-MOBILHY experiment. Agricultural and Forest Meteorology, 1992; 58: 285-313.

[37] Shuttleworth W J. Evaporation models in hydrology. In: Schmugge T J, Andre' J C (Eds.), Land Surface Evaporation, Measurement and Parameterization. Springer, New York, pp 93-120, 1991

[38] Rochette P, Pattey E, Desjardins R L O, Dwyer L W, Stewart D W. Estimation of maize canopy conductance by scaling up leaf stomatal conductance. Agricultural and Forest Meteorology, 1991; 54: 241-261.

[39] Duchemin B, Hadria R, Erraki S. Monitoring wheat phenology and irrigation in Central Morocco: On the use of relationships between evapotranspiration, crops coefficients, leaf area index and remotely-sensed vegetation indices. Agricultural Water Management, 2006; 79:1-27.

[40] Weng D M, Chen W L, Shen J C, Gao J B. Micro-climate and farmland micro-climate. Agricultural Press, Beijing, China, pp 6-144, 1981.

[41] Balwinder-Singh P L, Eberbacha E, Humphreysb S S. The effect of rice straw mulch on evapotranspiration, transpiration and soil evaporation of irrigated wheat in Punjab, India. Agricultural Water Management, 2011; 98: $1847-1855$

[42] Zhang H, Oweis T. Water-yield relations and optimal irrigation scheduling of wheat in the Mediterranean region. Agric Water Manage, 1999; 38: 195-211.

[43] Rafael R, Josef T. Surface renewal and eddy covariance measurements of sensible and latent heat fluxes of cotton during two growing seasons. Biosystems Engineering, 2015, 136: 149-16.

[44] Gao Z Q, Yin J, Miao G Y, Gao F W. Effects of tillage and mulch methods on soil moisture in wheat fields of the Loess Plateau, China. Pedosphere, 1999; 9: 161-168. 